\title{
PRELIMINARY STUDY ON MINOR ACTINIDE INCINERATION IN RSG-GAS WITHOUT ISOTOPE SEPARATION
}

\section{STUDI AWAL INSINERASI AKTINIDA MINOR DI RSG-GAS TANPA SEPARASI ISOTOP}

\author{
R. Andika Putra Dwijayanto1,2, Muhammad Alfarisie ${ }^{3}$ \\ 1 Department of Nuclear Engineering and Physics Engineering, Engineering Faculty, Universitas Gadjah Mada, Jl. Grafika \\ No. 2, Yogyakarta, Indonesia 55281 \\ 2 Centre for Nuclear Reactor Technology and Safety, National Nuclear Energy Agency, Building No. 80 Puspiptek Area, Setu, \\ South Tangerang 15310, Indonesia \\ ${ }^{3}$ Centre for Multipurpose Reactor, National Nuclear Energy Agency, Building No. 30 Puspiptek Area, Setu, South Tangerang \\ 15310, Indonesia \\ Email: putra-dwijayanto@batan.go.id
}

Received 14 February 2021, Received in revised form 21 July 2021, Accepted 21 July 2021

\begin{abstract}
PRELIMINARY STUDY ON MINOR ACTINIDE INCINERATION IN RSG-GAS WITHOUT ISOTOPE SEPARATION. Minor actinides (MA) produced from nuclear power plants is often considered as a nuisance in spent fuel management due to its considerably long half-life. One of available strategies to deal with MA is to incinerate it, in order to reduce its radioactivity. This paper presents a study on MA incineration in RSGGAS research reactor. Unlike previous study, this work did not separate the MA into individual isotopes, but instead they are incinerated as a whole. ORIGEN2.1 code is employed to calculate MA incineration within RSG-GAS core. MA composition used in this study consists of $\mathrm{Np}, \mathrm{Am}$, and $\mathrm{Cm}$ isotopes. The Central Irradiation Position (CIP) of RSG-GAS is loaded with $6 \mathrm{~kg}$ of MA and irradiated for two years. The result shows that about $1 \mathrm{~kg}$ of MA were incinerated after two years of irradiation, or $18.87 \%$ of the initial concentration. However, the increase of $\mathrm{Cm}$-242 isotope, along with newly-formed Pu isotopes, were found to be significantly increasing short-term radioactivity compared to unirradiated MA. Thus, two years-worth of MA incineration cannot be considered as effective, and other strategies must be pursued.
\end{abstract}

Keywords RSG GAS, minor actinide, transmutation, radioactivity.

\section{ABSTRAK}

STUDI AWAL INSINERASI AKTINIDA MINOR DI RSG-GAS TANPA SEPARASI ISOTOP. Aktinida minor (minor actinide/MA) yang dihasilkan dari pembangkit listrik tenaga nuklir sering dianggap sebagai masalah dalam manajemen bahan bakar nuklir bekas karena umur paruhnya yang panjang. Salah satu strategi yang dapat dilakukan untuk mengatasinya adalah dengan insinerasi MA, untuk menurunkan radioaktivitasnya. Artikel ini merupakan studi insinerasi MA di Reaktor Serba Guna-G.A. Siwabessy (RSG-GAS). Berbeda dengan penelitian sebelumnya, penelitian ini tidak melakukan separasi MA menjadi isotop-isotop individu, tetapi diinsinerasi secara keseluruhan. Kode komputer ORIGEN2.1 digunakan untuk mengkalkulasi insinerasi aktinida minor di dalam teras RSG-GAS. Komposisi MA yang digunakan terdiri dari isotop Np, Am, dan Cm. Central Irradiation Position (CIP) RSG-GAS dimuat dengan $6 \mathrm{~kg}$ aktinida minor dan diiradiasi selama dua tahun kalender. Dari hasil kalkulasi, ditemukan bahwa sekitar $1 \mathrm{~kg}$ MA berhasil diinsinerasi setelah dua tahun iradiasi, atau 18,87\% dari konsentrasi awal. Namun, kenaikan massa isotop Cm-242, beserta isotop Pu yang baru terbentuk, menyebabkan kenaikan radioaktivitas jangka pendek secara drastis dibandingkan MA yang tidak diinsinerasi. Dengan demikian, insinerasi MA selama dua tahun tidak bisa dianggap efektif, sehingga harus dipertimbangkan strategi lain.

Kata kunci RSG GAS, aktinida minor, transmutasi, radioaktivitas.

\section{INTRODUCTION}

In the management of spent nuclear fuel (SNF), minor actinide (MA) has long become an issue waiting to be resolved. MA, consisting primarily of neptunium, americium, and curium, is the primary source of long-lived radioactivity in SNF [1]. In the light of overly strict radiation protection regulatory, the existence of MA in SNF is considered as a potential radiation hazard if not managed properly. 
Jurnal Iptek Nuklir Ganendra

Ganendra Journal of Nuclear Science and Technology

Vol. 21 No.2, Juli-2021: 85-92

MA incineration is one of the available methods to get through the issue. Irradiating MA in several types of nuclear reactor can result in negative MA growth, meaning that less MA is generated compared to MA incinerated. Fast reactor is usually preferred to incinerate MA and considered in many studies [1-7]. Nevertheless, MA incineration can also be performed in thermal reactor, both research reactor [8] and power reactor [9-13].

Reaktor Serba Guna-G.A. Siwabessy (RSG-GAS) is a pool-type multipurpose research reactor owned and operated by Indonesian National Nuclear Energy Agency (BATAN). RSG-GAS has been utilised for various purposes, such as material testing, nuclear fuel irradiation test, radioisotope generation, and gemstone irradiation (e.g. topaz). Due to its high neutron flux, averaging $2 \times 10^{14}$ neutrons $/ \mathrm{cm}^{2} . \mathrm{s}$ at maximum power, RSG-GAS has a potential for MA incineration, although this capability is barely explored [14].

One preliminary study and another evaluation of RSG-GAS for MA transmutation have been performed [8, 15]. However, the latter did not elaborate several critical points, especially the total mass change and the resulting radioactivity, both in short and long-term. The study was also limited in term of MA choice, only using Am-241 as the reference isotope. More often than not, studies on MA incineration do not separate the actinides into isotopic level. The MA, from $\mathrm{Np}$ to $\mathrm{Cm}$, is left unseparated and burned as a whole in the reactor core $[1,5$, 16,17]. It makes no economic sense to partition MA nuclides into separate isotopes just to incinerate it, thus the MA is better left not partitioned.

This study explores the MA incineration in RSG-GAS without isotope separation, where short and longterm radioactivity of irradiated MA were evaluated. Other actinides that built up as the result of irradiation were also analysed. The MA inventory calculation was performed using ORIGEN2.1, which often used in radionuclide buildup and decay cases.

\section{METHODOLOGY}

RSG-GAS has nominal thermal power of $30 \mathrm{MW}$. It is moderated by light water, whilst beryllium is placed on the core perimeter as neutron reflector. The core consists of 40 standard fuel elements (FEs) and eight control elements (CEs) within a 10×10 grid. Each FE consists of 21 fuel plates in form of uranium silicide $\left(\mathrm{U}_{3} \mathrm{Si}_{2}-\mathrm{Al}\right)$, whilst CE only contains 15 fuel plates, leaving the room for control rod insertion [14, 18, 19].

In-core irradiation is served in eight grids, divided into one Central Irradiation Position (CIP) and four Irradiation Positions (IPs). CIP consists of four grids and usually used for larger irradiation target. At maximum power, RSG-GAS can achieve average neutron flux of about $2 \times 10^{14}$ neutrons $/ \mathrm{cm}^{2} . \mathrm{s}$ [14]. To maximise MA loading, CIP will be used in this study.

ORIGEN2.1 computer code was employed to calculate MA inventory after irradiation. It is a versatile code widely used to calculate buildup and decay of radioactive materials for various purposes [20]. The code solves the radioactivity buildup and decay using Bateman equation and one-group neutron cross section library. The former is represented in Equation 1.

$$
\frac{d X_{i}}{d t}=\sum{ }_{i j} \lambda_{j} X_{j}+\varphi \ddot{\sum} f_{i k} \sigma_{k} X_{k}-\left(\lambda_{i}+\varphi \sigma_{i}+r_{i}\right) X_{i}+F_{i}, \quad i=1, \ldots, N
$$

where $X_{i}$ denotes nuclide $i$ density, $N$ represents the number of nuclides, $l_{i j}$ represents radioactive disintegration fraction by other nuclide that leads to species $i$ formation, $j$ represents iterations number from $j=$ 1 to $j=N, \varphi$ denotes position and energy-averaged neutron flux, $f_{i k}$ represents fraction of neutron absorbed by other nuclides that leads to species $i$ formation, $\sigma_{k}$ denotes averaged neutron absorption cross section for nuclide $k, r_{i}$ denotes continuous removal rate of nuclide $i$ out from the system, and $F_{i}$ represents continuous feed rate of nuclide $i$.

The method explored in this study is to irradiate the MA for two years in which the isotopes are left unseparated. The analysis was performed in isotopic level. The MA is composed of $\mathrm{Np}, \mathrm{Am}$, and $\mathrm{Cm}$ isotopes, where the isotopic vector provided in Table 1. The MA are in metallic form and enclosed in a cladding. The isotopic vector is taken from reference [21]. 
Table 1. Isotopic composition of MA.

\begin{tabular}{ll}
\hline Isotope & Vector (\%) \\
\hline $\mathrm{Np}-237$ & 42.25 \\
$\mathrm{Am}-241$ & 47.57 \\
$\mathrm{Am}-243$ & 8.50 \\
$\mathrm{Cm}-242$ & 0.32 \\
$\mathrm{Cm}-243$ & 0.01 \\
$\mathrm{Cm}-244$ & 1.26 \\
$\mathrm{Cm}-245$ & 0.07 \\
$\mathrm{Cm}-246$ & 0.01 \\
\hline
\end{tabular}

Setiawan et al. [8] mentioned that the maximum MA loading in the CIP is limited to $8 \mathrm{~kg}$ to maintain operational parameters within safety criteria. This study set the MA loading at $6 \mathrm{~kg}$, below the said limit. The mass of each isotope is calculated according to isotopic vector in Table 1.

Burnup scheme in ORIGEN2.1 is available in two options, namely constant power (IRP) and constant flux (IRF) [22]. This study involves irradiation with predetermined input of neutron flux, and thus IRF scheme was employed. Since RSG-GAS is a thermal reactor, the cross section used is adjusted to thermal neutron library.

Irradiation time was in accordance to RSG-GAS operational schedule for Year 2020 [23]. Since the calculation was performed for two years, and the operational schedule is arranged annually, it was assumed that the irradiation time in second year mirrors the first year completely. Neutron flux for the code input was also taken from reference [8] for MA loading of $6 \mathrm{~kg}$.

After irradiation, the MAs were decayed for up to 500 years. To evaluate the radioactivity, decay-only calculations were performed also for 500 years. Total radioactivity from residual MA and generated MA after irradiation is compared with MA radioactivity without irradiation. Meanwhile, incineration efficiency is calculated using the Equation 2 [24].

$$
\text { Efficiency }=100 \%-\frac{M A_{\text {result }}}{M A_{\text {initial }}}
$$

Equation 2 ignores the buildup of other MA nuclides due to irradiation. Thus, it does not necessarily represent total mass change and resulting radioactivity, only the reduction of said MA isotope.

\section{RESULT AND DISCUSSIONS}

The result is divided into three separate subsections, namely MA incineration, isotope evolution, and radioactivity.

\section{MA Incineration}

Table 2 shows that Np-237 was incinerated in a much slower rate than Am-241, despite the similarity of initial mass. The remaining $\mathrm{Np}$ after two years-worth of irradiation is around 7.5 times larger than Am-241, and more than twice larger than total Am isotopes. The incineration efficiency of $\mathrm{Np}$ is about $41.77 \%$, Am is $81.98 \%$, and $\mathrm{Cm}$ is $-389 \%$. The negative efficiency of $\mathrm{Cm}$ is because its total mass was increasing instead of decreasing.

Mass increase of most $\mathrm{Cm}$ isotopes (except $\mathrm{Cm}-245$ ) suggests that not all the mass change was caused by fission, but partially by transmutation. This is understandable since $\mathrm{Cm}$ is a transmutation product from successive neutron capture from Am, which has higher neutron capture cross section than fission cross section in thermal spectrum [25]. The residual mass from $\mathrm{Cm}$ isotopes will have a significant effect in the radioactivity, as will be discussed later.

Mass change occurred most drastically in the first year of irradiation. The key of this phenomenon is the characteristic of Am-241. Its thermal neutron capture cross-section is the largest among other MA isotopes, combined with highest mass percentage. Therefore, Am-241 is more likely to capture neutron, and consequently transmute the fastest. This result is consistent with previous studies in other type of reactors $[10,11]$. 
Jurnal Iptek Nuklir Ganendra

Ganendra Journal of Nuclear Science and Technology

Vol. 21 No.2, Juli-2021: 85-92

Mass change of the incinerated MA is shown in Table 2.

Table 2. Mass change for MA.

\begin{tabular}{llll}
\hline Isotope & Initial Mass $\mathbf{( g )}$ & Mass After 1 Year $\mathbf{( g )}$ & Mass After 2 Years $\mathbf{( g )}$ \\
\hline $\mathrm{Np}-237$ & $2,535.00$ & $1,937.00$ & $1,476.00$ \\
$\mathrm{Am}-241$ & $2,854.20$ & 749.80 & 195.70 \\
$\mathrm{Am}-243$ & 510.00 & 454.60 & 410.30 \\
$\mathrm{Cm}-242$ & 19.20 & 706.60 & 297.90 \\
$\mathrm{Cm}-243$ & 0.60 & 9.05 & 8.52 \\
$\mathrm{Cm}-244$ & 75.60 & 132.20 & 180.70 \\
$\mathrm{Cm}-245$ & 4.20 & 0.78 & 1.00 \\
$\mathrm{Cm}-246$ & 0.60 & 1.44 & 1.92 \\
\multicolumn{2}{l}{ Mass Difference } & $-2,007.93$ & $-3,427.36$ \\
\hline
\end{tabular}

Table 3. MA fomed by irradiation.

\begin{tabular}{lll}
\hline Isotope & Mass After 1 Year $\mathbf{( g )}$ & Mass After 2 Year $(\mathbf{g})$ \\
\hline Am-242m & 8.74 & 2.26 \\
Pu-238 & 920.60 & $1,137.00$ \\
Pu-239 & 272.80 & 546.00 \\
Pu-240 & 42.31 & 187.90 \\
Pu-241 & 3.67 & 25.70 \\
Pu-242 & 313.70 & 395.80 \\
Total & $1,561.82$ & $2,294.66$ \\
Fissioned MA & 446.11 & $1,132.70$ \\
\hline
\end{tabular}

After a year, Am-241 mass was reduced considerably so that its macroscopic capture cross section was no longer the largest. Neutron capture was then dominated by $\mathrm{Cm}$, since its mass was increased during the first year as a transmutation and decay product of Am. That explains why $\mathrm{Cm}$ mass was decreasing in the second year. $\mathrm{Cm}-242$ has the shortest half life among the selected MA. Thus, the decrease of $\mathrm{Cm}$ in the second year can also be contributed by $\mathrm{Cm}-242$ decay. However, the exact proportion of neutron capture and decay in the $\mathrm{Cm}$ mass reduction is unknown, as ORIGEN2.1 does not provide such data. Modified CITATION code is able to extract transmutation matrix of MA nuclides [5], but no such capability is found in ORIGEN. Nonetheless, it can probably be estimated by the buildup of Pu-242 isotope, as it is a direct decay product of $\mathrm{Cm}-242$.

Table 2 only shows mass change, ignoring whether the reduced MA are fissioned or simply transmuted into another MA. To provide a better perspective, Table 3 shows other actinides formed by MA irradiation and MA mass that actually fissioned.

Despite significant mass change in initial MA, the amount of MA that actually fissioned was less than half of it. Most fission event occured in the second year of irradiation as opposed to mass change. The rest of mass change was contributed by transmutation. Thus, the mass change was not actually caused by fission but rather by transmutation into other MA, mostly Pu. As previously mentioned, this is due to the neutron capture cross section of MA isotopes in thermal spectrum is generally higher than their fission cross section, save for a small number of isotopes [25].

The resulting Pu isotopes are mostly Pu-238, which formation was larger in the first year of irradiation. Its purity was low, amounting around half of total Pu concentration. Pu-238 is useful for several applications such as radioisotope thermoelectric generator (RTG), but the purity must be high. Pu-238 resulted from MA irradiation in RSG-GAS is therefore unsuitable for such application and practically has no economic value.

The residual mass of Pu-242 can used to determine the decay of $\mathrm{Cm}-242$, as the former is a decay daughter of the latter through $2 \beta^{+}$decay. As seen in Table 3, Pu-242 in both compositions are larger than Pu-240. As Pu isotopes are formed by successive neutron capture, Pu-242 mass must be the lowest. Yet, its mass is comparably large. Therefore, it can be safely concluded that most of $\mathrm{Pu}-242$ was formed as a result of $\mathrm{Cm}-242$ 
decay. Since Pu-242 formation from the first year to the second year was smaller than in the first year, it can also be concluded that the fraction of fissioned $\mathrm{Cm}-242$ was larger in the second year of irradiation.

In total, the amount of incinerated MA after two years of irradiation is around $18.87 \%$ of its initial mass. This efficiency only accounts for fissioned MA, not considering MA isotopes that were transmuted instead of fissioned. The efficiency is not too dissimilar with other references [11, 24], but the required time was around twice as long.

\section{Isotope evolution}

$\mathrm{Cm}$ buildup lasts less than a year before being decreased, when Am mass has lowered enough so that the former has its transmutation rate higher than its buildup rate. At the end of irradiation, the highest remaining $\mathrm{MA}$ were $\mathrm{Np}$ and $\mathrm{Am}$. However, mass difference between Am and $\mathrm{Cm}$ is quite small. The pattern is different with MA incineration in molten salt reactors in reference [25], but it must be noted that the MA load in the said reactors is significantly higher due to them being power reactor. The main difference is that the mass of $\mathrm{Cm}$ isotopes are still increasing in other references, once again due to significantly higher MA load [24, 25].

During irradiation, isotopes are transmuted and fissioned. The buildup and decrease of initial MA isotopes are shown in Figure 1.

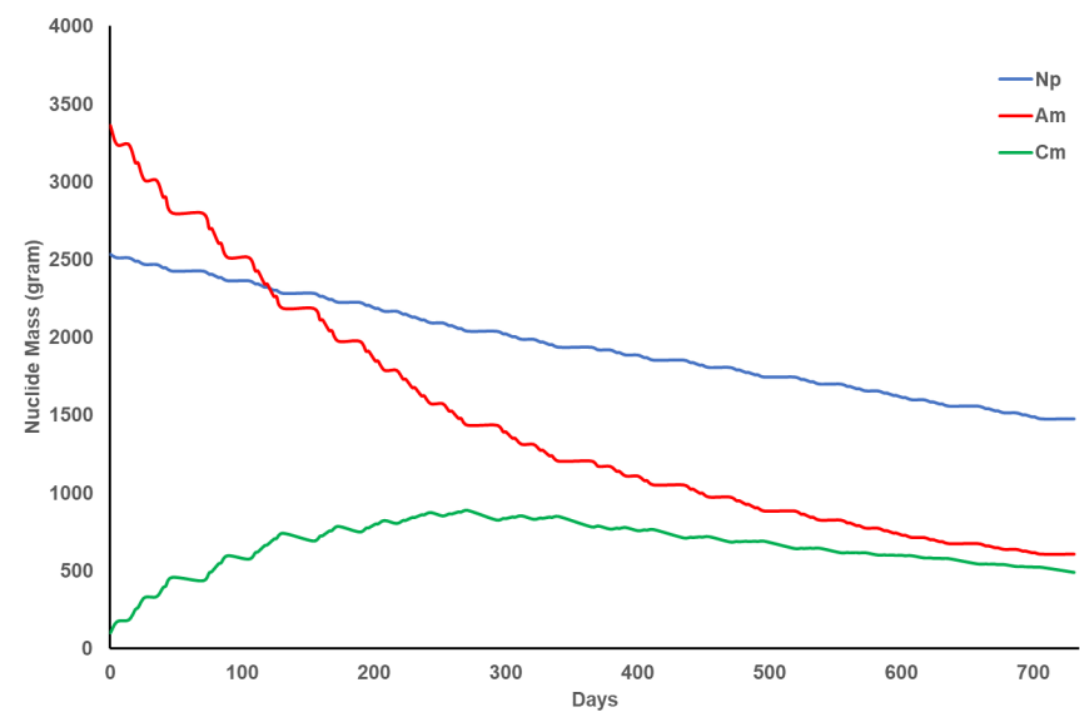

Figure 1. Initial MA mass change.

Figure 2 shows the buildup of Pu isotope from MA irradiation.

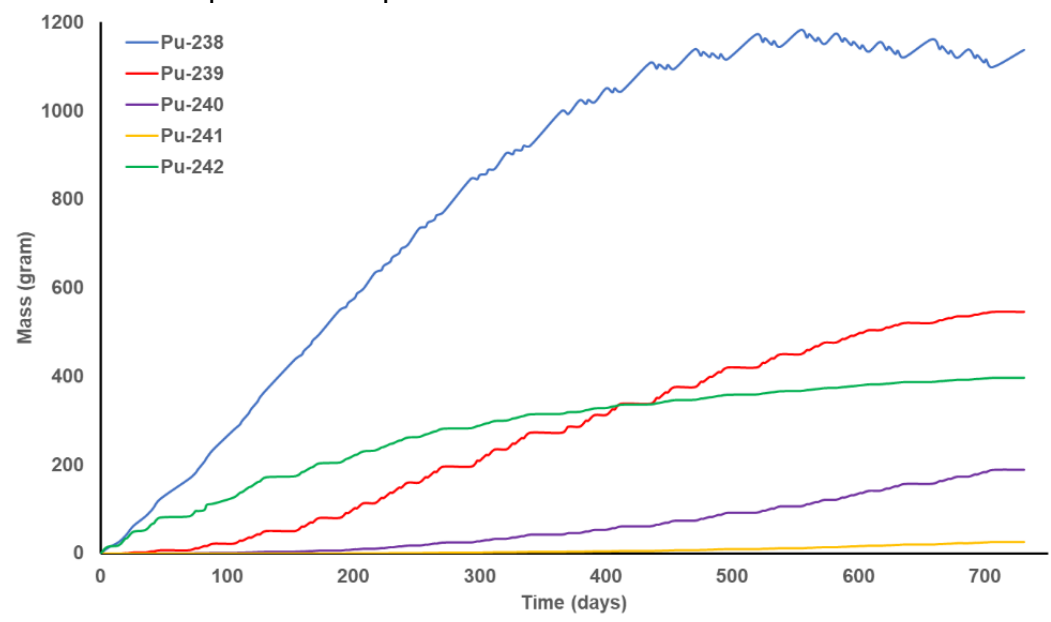

Figure 2. Pu buildup. 
Jurnal Iptek Nuklir Ganendra

Ganendra Journal of Nuclear Science and Technology

Vol. 21 No.2, Juli-2021: 85-92

Pu-238 isotope dominates the buildup. Its buildup saturates in around day 500 of irradiation, after that its irradiation and decay rate were relatively stable until end of irradiation. The buildup of fissile Pu-239 was initially slower before overtaking Pu-242 after day 400 of irradiation. At the end of irradiation, Pu-242 became the second-largest residual $\mathrm{Pu}$ isotope. $\mathrm{Pu}-242$ is a fissionable isotope with low capture neutron cross-section. It contributes less to MA radioactivity than Pu-239, a fissile isotope with shorter half-life. Although the Pu was already denaturised in such a way that it cannot be proliferated by any means, the highly politicised nature of nuclear waste management might favour as little fissile isotope as possible. Thus, high buildup of Pu-242 in the MA is quite appealing.

\section{Radioactivity}

Evaluating the radioactivity is necessary to prevent short-term and long-term radiological issues, especially since MA incineration is intended to reduce its own radioactivity. The easiest way is to compare the decay radioactivity from irradiated MA with unirradiated MA. The comparisons are provided in Table 4. It must be noted that the radioactivity for irradiated MA does not include FP radioactivity.

Table 4. MA radioactivity after 500 years of decay (Curie).

\begin{tabular}{lll}
\hline Year & \multicolumn{2}{c}{ MA1 } \\
\cline { 2 - 3 } & Total & No Burnup \\
\hline 0 & $1,023,522.92$ & $79,560.00$ \\
1 & $250,031.95$ & $29,630.00$ \\
5 & $39,415.48$ & $15,350.00$ \\
10 & $35,503.12$ & $14,350.00$ \\
20 & $29,929.10$ & $12,850.00$ \\
30 & $25,737.48$ & $11,770.00$ \\
40 & $22,507.98$ & $10,980.00$ \\
50 & $19,964.09$ & $10,400.00$ \\
100 & $12,380.24$ & $8,855.00$ \\
200 & $5,831.86$ & $7,404.00$ \\
300 & $2,975.66$ & $6,310.00$ \\
500 & $1,016.02$ & $4,621.00$ \\
\hline
\end{tabular}

Two years-worth of MA irradiation resulted in a significantly higher radioactivity for the first 200 years of decay. $\mathrm{Cm}$ formation is the main source of radioactivity, especially $\mathrm{Cm}-242$, which contributed more than $90 \%$ of the radioactivity after discharge. It has a relatively short half-life, nevertheless, and its radioactivity was greatly reduced after fifth year of discharge. The greater concern in longer term were Pu-238 and Cm-244, which became the two largest contributors of radioactivity after $\mathrm{Cm}-242$ decay. The large contribution of $\mathrm{Cm}-244$ to radioactivity implies that the difference of few dozens of grams of $\mathrm{Cm}$ can significantly increases the radioactivity after irradiation, and thereby must be considered carefully.

It must be realised that high radioactivity can lead to more issues in short-term. A large number of Pu-238 releases considerable amount of decay heat that needs to be dissipated properly. Remote handling will be even more challenging to perform. Not to mention the resulting FPs that are not shown in the table; its addition will make short-term radioactivity even higher. This can potentially complicate irradiated MA handling instead of easing the radioactivity burden. Since it takes 200 years before the radioactivity of irradiated MA to become lower than unirradiated MA, this finding raises a question about the feasibility of two-years irradiation strategy in current study. Longer irradiation time might be necessary to prevent short-term issue.

\section{CONCLUSIONS}

MA incineration without isotopic separation is shown to be troublesome in short-term, i.e., the first 200 years after discharge. Although a large fraction of Am-241 and Np-237 were able to be transmuted, the residual $\mathrm{Cm}$ and $\mathrm{Pu}$ isotopes are proven to be significantly increasing the radioactivity for the aforementioned timescale 
compared to unirradiated MA. How much the short-term radioactivity increase differs from MA incineration with isotope separation is unknown, as previous study did not provide the numbers. Nevertheless, this result is concerning, as the objective of MA transmutation is to reduce the radioactivity hazard both short and long-term. As a whole, MA incineration for two years without isotopic separation is not deemed feasible. In order to prevent short-term concern from arising, other strategy must be pursued if RSG-GAS were to be employed as MA incinerator.

\section{ACKNOWLEDGMENT}

This work is supported by research budget of Centre for Nuclear Reactor Technology and Safety, Fiscal Year 2020. The first author would like to express gratitude to Mrs. Ihda Husnayani for the discussions to improve the manuscript. R. Andika Putra Dwijayanto is the main contributor of the article.

\section{REFERENCES}

[1] C. Yu et al., "Minor actinide incineration and Th-U breeding in a small FLiNaK Molten Salt Fast Reactor," Ann. Nucl. Energy, vol. 99, pp. 335-344, 2017.

[2] T. Takeda, "Minor actinides transmutation performance in a fast reactor," Ann. Nucl. Energy, vol. 95, pp. 48-53, 2016.

[3] K. Allen and T. Knight, "Destruction rate analysis of transuranic targets in sodium-cooled fast reactor (SFR) assemblies using MCNPX and SCALE 6.0," Prog. Nucl. Energy, vol. 52, no. 4, pp. 387-394, 2010.

[4] B. Liu, J. Han, F. Liu, J. Sheng, and Z. Li, "Minor actinide transmutation in the lead-cooled fast reactor," Prog. Nucl. Energy, vol. 119, 2020.

[5] H. N. Tran, Y. Kato, P. H. Liem, V. K. Hoang, and S. M. T. Hoang, "Minor Actinide Transmutation in Supercritical-CO2-Cooled and Sodium-Cooled Fast Reactors with Low Burnup Reactivity Swings," Nucl. Technol., vol. 205, no. 11, pp. 1460-1473, 2019.

[6] H. Ohta, T. Ogata, S. Van Winckel, D. Papaioannou, and V. V. Rondinella, "Minor actinide transmutation in fast reactor metal fuels irradiated for 120 and 360 equivalent full-power days," J. Nucl. Sci. Technol., vol. 53, no. 7, pp. 968-980, 2016.

[7] T. Kooyman, L. Buiron, and G. Rimpault, "Optimization of minor actinide-bearing radial blankets for heterogeneous transmutation in fast reactors," Nucl. Sci. Eng., vol. 185, no. 2, pp. 335-350, 2017.

[8] M. B. Setiawan, S. Kuntjoro, I. Husnayani, P. M. Udiyani, and T. Surbakti, "Evaluation on transmutation of minor actinides discharged from PWR spent fuel in the RSG-GAS research reactor," Malaysian $\mathrm{J}$. Fundam. Appl. Sci., vol. 15, no. 4, pp. 577-579, 2019.

[9] B. Liu, R. Jia, R. Han, X. Lyu, J. Han, and W. Li, "Minor actinide transmutation characteristics in AP1000," Ann. Nucl. Energy, vol. 115, pp. 116-125, 2018.

[10] W. Hu, J. Jing, J. Bi, C. Zhao, B. Liu, and X. Ouyang, "Minor actinides transmutation on pressurized water reactor burnable poison rods," Ann. Nucl. Energy, vol. 110, pp. 222-229, 2017.

[11] V. T. Tran, H. N. Tran, H. T. Nguyen, V. K. Hoang, and P. N. V. Ha, "Study on Transmutation of Minor Actinides as Burnable Poison in VVER-1000 Fuel Assembly," Sci. Technol. Nucl. Install., 2019.

[12] M. Hussain and M. Sohail, "Feasibility study of transmutation of minor actinides in PWR fuel assembly," in ICET 2016 - 2016 International Conference on Emerging Technologies, 2017, pp. 16-19.

[13] J. Washington and J. King, "Optimization of plutonium and minor actinide transmutation in an AP1000 fuel assembly via a genetic search algorithm," Nucl. Eng. Des., vol. 311, pp. 199-212, 2017.

[14] S. Pinem, T. M. Sembiring, and P. H. Liem, "Neutronic and Thermal-Hydraulic Safety Analysis for the Optimization of the Uranium Foil Target in the RSG-GAS Reactor," Atom Indones., vol. 42, no. 3, p. 123, 2016.

[15] M. B. Setiawan and S. Kuntjoro, "Preliminary Analysis of High-Flux RSG-GAS to Transmute Am-241 of PWR's Spent Fuel in Asian Region," in Journal of Physics: Conference Series, 2018, vol. 962, no. 1, p. 
12004.

[16] V. Ignatiev et al., "Molten salt actinide recycler and transforming system without and with Th-U support: Fuel cycle flexibility and key material properties," Ann. Nucl. Energy, vol. 64, pp. 408-420, 2014.

[17] K. Tuček, J. Carlsson, D. Vidović, and H. Wider, "Comparative study of minor actinide transmutation in sodium and lead-cooled fast reactor cores," Prog. Nucl. Energy, vol. 50, no. 2-6, pp. 382-388, 2008.

[18] P. H. Liem, T. Surbakti, and D. Hartanto, "Kinetics parameters evaluation on the first core of the RSG GAS (MPR-30) using continuous energy Monte Carlo method," Prog. Nucl. Energy, vol. 109, pp. 196-203, 2018.

[19] S. Kuntjoro, P. M. Udiyani, and M. Budi Setiawan, "Fuel Burn-up and Radioactivity Inventory Analysis for New In-core Fuel Management of the RSG-GAS Research Reactor," in Journal of Physics: Conference Series, 2019, vol. 1198, no. 2.

[20] I. Husnayani and P. M. Udiyani, "Radionuclide Characteristics of RDE Spent Fuels," Tri Dasa Mega, vol. 20, no. 2, pp. 69-76, 2018.

[21] A. Waris, I. K. Aji, S. Pramuditya, Novitrian, S. Permana, and Z. Su'ud, "Comparative Studies on Plutonium and Minor Actinides Utilization in Small Molten Salt Reactors with Various Powers and Core Sizes," Energy Procedia, vol. 71, pp. 62-68, 2015.

[22] M. Zheng et al., "Development of a MCNP - ORIGEN burn-up calculation code system and its accuracy assessment," Ann. Nucl. Energy, vol. 63, pp. 491-498, 2014.

[23] PRSG BATAN, "Jadwal Operasi Reaktor GA Siwabessy," 2019. [Online]. Available: http://www.batan.go.id/index.php/id/fasilitas-prsg-2. [Accessed: 05-Jan-2020].

[24] B. Liu, J. Han, F. Liu, J. Sheng, and Z. Li, "Minor actinide transmutation in the lead-cooled fast reactor," Prog. Nucl. Energy, vol. 119, p. 103148, 2020.

[25] O. Ashraf and G. V. Tikhomirov, "Thermal-and fast-spectrum molten salt reactors for minor actinides transmutation," Ann. Nucl. Energy, vol. 148, p. 107751, 2020. 